\title{
PENYELESAIAN PERKARA PIDANA MELALUI MEDIASI PENAL: ACCESS TO JUSTICE DI TINGKAT KEPOLISIAN
}

\author{
Oleh: \\ Cahya Wulandari \\ Fakultas Hukum, Universitas Negeri Semarang 50229, Semarang, Indonesia \\ E-mail: cahyawulandari@yahoo.com
}

\begin{abstract}
ABSTRAK
Penanggulangan perkara pidana yang terjadi di tengah masyarakat dapat diselesaikan dengan dua metode, yaitu penal dan non penal. Penyelesaian secara non penal salah satunya merupakan Mediasi Penal. Mediasi penal sendiri lahir dari budaya yang ada di dalam masyarakat sehingga kandungan nilai-nilainya sesuai dengan karakteristik Bangsa Indonesia. Namun penerapan mediasi penal ini belum memiliki landasan yuridis yang kuat sehingga perlu diteliti lebih lanjut apa model mediasi yang digunakan serta bagaimana peran aparat penegak hukum. Dalam artikel ini akan dipaparkan proses penyelesaian perkara pidana melalui mediasi penal di tingkat penyidikan dan peran aparat penegak hukum dalam proses mediasi penal. Data pendukung artikel ini menggunakan hasil penelitian dengan jenis kualitatif dan metode pendekatan yuridis sosiologis yang mendasarkan pada data primer dan data sekunder. Pada dasarnya, mediasi penal telah familiar dilaksanakan ditingkat kepolisian didasarkan pada Surat Kapolri No Pol: B/3022/XII/2009/SDEOPS tanggal 14 Desember 2009 tentang Penanganan Kasus Melalui Alternatif Dispute Resolution dengan bentuk mediasi penal yang digunakan adalah victim offender mediation. Model VOM ini dianggap paling layak untuk diterapkan karena mempertemukan antara kedua belah pihak sehingga mengakomodir kepentingan para pihak demi terwujudnya keadilan restoratif.
\end{abstract}

\section{Kata Kunci : Mediasi Penal, Acces to Justice, Victim Offender Mediation}

\begin{abstract}
Overcoming criminal cases that occur in the middle of society can be solved by two methods, namely reasoning and non-punishment. Non-reasoning settlement is one of them is Penal Mediation. The reasoning mediation itself is born from the culture that exists in society so that the content of its values is in accordance with the characteristics of the Indonesian Nation. However, the application of this reasoning mediation does not yet have a strong juridical basis so it needs to be investigated further what the mediation model is used and how the role of law enforcement officers is. In this article will be presented the process of solving criminal cases through reasoning mediation at the level of investigation and the role of law enforcement officers in the process of judicial mediation. Supporting data for this article uses the results of research with qualitative types and sociological juridical approaches that base on primary data and secondary data. Basically, the reasoning mediation is familiar is carried out at the police level based on National Police Chief No Pol: B / 3022 / XII / 2009 / SDEOPS dated December 14, 2009 concerning Case Handling through Dispute Resolution Alternatives with the form of reasoning mediation that is victim offender mediation. This VOM model is considered the most feasible to implement because it brings together the two parties so that it accommodates the interests of the parties in order to realize restorative justice.
\end{abstract}

\section{Keywords: Penal Mediation, Access to Justice, Victim Offender Mediation}




\section{A. LATAR BELAKANG}

Aristoteles menyatakan bahwa manusia merupakan makhluk sosial, artinya manusia tidak bisa memenuhi segala kebutuhannya seorang diri. Dalam kehidupan bermasyarakat tidak terlepas dari adanya gesekan antar kepentingan baik antar individu maupun dengan masyarakat luas. Permasalahan tersebut dilatarbelakangi oleh perbedaan kepentingan sosial, budaya, ekonomi, dan faktor lainnya antara satu dan yang lain. Permasalahan tersebut membentuk pola penyelesaian yang berasal dari kebudayaan masyarakat itu sendiri. Fenomena perselisihan dan atau pertengkaran yang terjadi di tengah-tengah masyarakat menjadi fakta yang tidak terbantahkan lagi. Manusia sebagai mahluk sosial, memiliki karakter kecenderungan untuk berkumpul dan bergaul. Masing-masing manusia memiliki karakter individual dan kepentingan personal yang berbeda-beda. Perbedaan karakter dan kepentingan individual yang bertemu dalam satu komunitas, melahirkan gesekan-gesekan, dan benturan-benturan karakter dan kepentingan yang menimbulkan perselisihan, permusuhan, dan pertengkaran.

Dalam sejarah hukum acara pidana di Indonesia, proses penyelesaian perselisihan dimulai dari terbentuknya peradilan adat. Struktur, model penyelesaian dan bentuk sanksi di peradilan adat ini terbentuk dari kebiasaan yang dianut oleh masyarakat setempat. Tentu peradilan adat ini sepenuhnya mengandung nilai-nilai moral masyarakat dan hukum yang digunakan sebagai legal substance adalah living law.

Living law merupakan hukum yang hidup dan diakui oleh masyarakat. Penggunaan living law sebagai sumber hukum peradilan adat tentu dijunjung tinggi oleh seluruh elemennya sehingga prosesnya dihormati sedemikian rupa. KUHP Indonesia tidak mengenal hukum tidak tertulis karena asas legalitas yang tercantum dalam Pasal 1 ayat (1) KUHP. Namun dalam RKUHP, hukum yang hidup dalam masyarakat akan menjadi sumber hukum yang sah secara yuridis yang tercantum dalam Pasal 2 ayat (1) RKUHP yang pada intinya menyatakan bahwa berlakunya legalitas formil tidak membatasi berlakunya legalitas materiil. Itu artinya suatu perbuatan dapat dipidana meskipun tidak diatur dalam undang-undang tapi dianggap patut dipidana oleh masyarakat. Ketentuan mengenai living law tersebut diatur kemudian dalam ayat (2) yang mensyaratkan living law tersebut haruslah sesuai dengan nilai-nilai yang terkandung dalam Pancasila, hak asasi manusia, dan prinsip-prinsip umum yang diakui oleh masyarakat bangsa-bangsa.

Dalam Pasal 18 b ayat (2) UUD NRI 1945 juga mnyatakan bahwa negara mengakui dan menghormati kesatuan-kesatuan masyarakat hukum adat beserta hak-hak tradisionalnya sepanjang masih hidup dan sesuai dengan perkembangan masyarakat dan prinsip NKRI yang diatur dalam undang-undang. 
Undang-undang Nomor 48 Tahun 2009 tentang Kekuasaan Kehakiman juga mengakui hukum yang hidup dalam masyarakat yaitu pada Pasal 50 ayat (1) yang menyataan bahwa putusan pengadilan selain harus memuat alasan dan dasar putusan, juga memuat pasal tertentu dari peraturan perundng-undangan yang bersangkutan atau sumber hukum tak tertulis yang dijadikan dasar untuk mengadili. Dari penjelasan tersebut, tersirat makna bahwa Undang-undang Kekuasaan Kehakiman mengakui adanya living law dan hakim harus menjadikan itu sebagai pertimbangan dalam mengambil keputusan.

Pengadilan bukanlah satu-satunya lembaga penyelesaian sengketa, tetapi ada lembaga lain yang diakui eksistensi dan perannya yang sangat penting dalam ikut mewujudkan keinginan masyarakat dalam penyelesaian perkara hukum pidana khususnya yaitu adanya penal mediation sebagai upaya penyelesaian perkara pidana di luar proses litigasi. Untuk mendukung upaya penyelesaian perkara pidana dengan menggunakan mediasi penal maka perlu adanya dukungan dari Pemerintah untuk membuat umbrella act bagi pelaksanaan mediasi di bidang pidana sebagai salah satu bentuk alternative dispute settlement.

Mediasi penal memiliki konsep yang baik dalam menegakkan perlindungan hukum bagi korban. Dengan adanya mediasi penal, tuntutan-tuntutan yang diharapkan oleh korban dapat terlaksana sehingga kebermanfaatan bagi masyarakat dapat terwujud. Oleh karena itu, mediasi penal merupakan salah satu acces to justice yang dapat ditempuh oleh korban ataupun pelaku. Acces to justice atau dalam bahasa Indonsia disebut Akses Menuju Keadilan adalah hak setiap orang untuk mendapatkan akses memperoleh keadilan yang merupakan Hak Asasi Manusia (Djohansjah, 2010 : 5). Penyelesaian melalui mediasi penal perlu digali lebih lanjut mengenai bentuk mediasi penal yang tepat untuk menyelesaikan perkara pidana sehingga aparat penegak hukum dapat memberikan peran dalam acces to justice secara maksimal untuk masyarakat.

\section{B. PERUMUSAN MASALAH}

1. Bagaimanakah bentuk penyelesaian perkara pidana melalui mediasi penal di tingkat kepolisian?

2. Bagaimanakah peran polisi dalam proses mediasi penal?

\section{METODE PENELITIAN}

\section{Metode Pendekatan}

Penelitian ini menggunakan metode yuridis sosiologis, jenis data kualitatif dengan menggunakan data primer dan data sekunder.

2. Metode Pengumpulan Data.

Sumber data yang penulis gunakan adalah data primer dan data sekunder. Data primer adalah data yang diperoleh langsung dari lapangan, dalam hal ini adalah aparat penegak hukum dalam 
lingkungan kepolisian dengan menggunakan teknik purposive sampling, yaitu pemilihan sample berdasarkan pertimbangan subjektif dari peneliti didasarkan atas ciri-ciri atau sifat-sifat tertentu yang dipandang mempunyai sangkut paut yang erat dengan objek yang akan dijadikan penelitian dan beberapa anggota masyarakat yang menyelesaikan tindak pidana menggunakan mediasi penal. Data sekunder adalah data yang diperoleh melalui bahan kepustakaan, dapat berupa peraturan perundang-undangan, buku, jurnal, artikel, kamus dan bahan hukum lainnya.

3. Metode Analisis Data.

Untuk penelitian ini, analisis data menggunakan interactive model of analysis. Pada model analisis interaktif ini peneliti bergerak pada tiga komponen, yaitu data reduksi (reduction data), data display dan Conclucying drawing (Miles \& Huberman, 1984).

\section{HASIL DAN PEMBAHASAN}

\section{D.1. Bentuk Penyelesaian Perkara Pidana Melalui Mediasi Penal}

\section{Penerapan Mediasi Penal di Tingkat Kepolisian}

Mediasi Penal belum memiliki legal standing yang kuat untuk diterapkan dalam penyelesaian kasus tindak pidana yang telah masuk pada instansi peradilan. Mediasi penal merupakan upaya penyelesaian kasus di luar pengadilan sehingga dengan masuknya suatu perkara di tingkat kepolisian dianggap suatu pilihan untuk menyelesaikannya di jalur hukum. Sampel Lembaga Kepolisian yang digunakan dalam penelitian ini adalah Polisi Sektor Tugu Semarang dan Polisi Sektor Polanharjo Klaten sehingga data yang diambil mengenai penyelesaian perkara pidana melalui mediasi penal diambil dari kedua tempat tersebut. Untuk memperkuat sumber tersebut, penelitian ini juga dilaksanakan di Polda Jawa Tengah.

Sebagaimana tersirat di dalam Pembukaan Undang-Undang Dasar 1945, hukum merupakan instrumen untuk mendukung terselenggaranya fungsi dan tugas negara untuk melindungi segenap bangsa dan tumpah darah Indonesia, memajukan kesejahteraan umum, mencerdaskan kehidupan bangsa, menciptakan perdamaian serta mewujudkan keadilan sosial bagi seluruh rakyat Indonesia. Maka dari itu, hal-hal yang perlu diperhatikan dari penerapan hukum yang sering terlupakan adalah tercapainya perlindungan bagi korban serta perdamaian kedua belah pihak atau lebih.

Penyelesaian perkara melalui mediasi penal awalnya hanya dikenal pada ranah penyelesaian perkara perdata. Meskipun perkara tersebut telah masuk ke lembaga peradilan, mediasi tetap ditawarkan kepada kedua belah pihak oleh aparat penegak hukum secara legal. Berbeda dengan perkara pidana, masyarakat menganggap bahwa penyelesaian melalui mediasi dapat ditempuh hanya sebelum kasus tersebut dilaporkan ke kepolisian.

Seringkali penyelesaian perkara pidana melalui jalur litigasi mengabaikan hal tersebut. Menimbang KUHAP memuat pengaturan secara terperinci hak-hak pelaku tindak pidana dalam satu bab, di bawah titel Hak-hak Tersangka dan Terdakwa dari Pasal 50 hingga 68. Jadi hak-hak pelaku 
tindak pidana diatur di dalam sejumlah 19 (sembilan belas) pasal. Sementara itu, hak korban tindak pidana, diatur di dalam 3 (tiga) pasal, yakni pada Pasal 98, 99, 100, di bawah titel Penggabungan Perkara Gugatan dan Ganti Kerugian (Surbakti, 2011: 91).

Pertimbangan hukum tersebut membuat posisi mediasi penal di tengah masyarakat sangat dibutuhkan kehadirannya untuk memenuhi hak dari korban. Pola-pola penyelesaian sengketa di berbagai masyarakat tradisional, pada dasarnya berorientasi pada tercapainya kepulihan atas semua dampak kerugian yang dialami oleh pihak korban. Dalam terminologi ilmiah (scientifiq) kontemporer filosofi peradilan yang berorientasi pada perbaikan atau pemulihan dampak kerugian yang diderita korban ini dikenal dengan teori peradilan restoratif (restorative justice theory). Penerapan konsep keadilan restorasi (restorative justice) dalam sistem peradilan hukum pidana di Indonesia merupakan kesempatan dan penawaran untuk dapat menanamkan nilai konservasi dalam aspek penegakan hukum di Indonesia. Konsep ini adalah paradigma yang masih terbilang baru di Indonesia. Berbeda dengan konsep keadilan retributif yang menekankan keadilan pada pembalasan saja dan konsep keadilan restitutif yang menekankan pada ganti kerugian pihak yang lemah. Konsep keadilan restorasi telah melampaui kedua konsep tersebut yaitu konsep yang berusaha mencapai keadilan melalui pemulihan keadaan setelah peristiwa dan proses hukum itu terjadi.

Restorative justice merupakan keadilan yang mengutamakan perdamaian antara pelaku, korban, dan masyarakat itu sendiri. Konsep ini juga disebut sebagai Just Peace Principle karena pendekatan kejahatan dalam hal ini adalah pemulihan kerusakan yang diakibatkan oleh kejahatan (it is an attempt to recovery justice) dengan mempertemukan tiga komponen tadi. Tentunya, konsep restoratif mengandung nilai-nilai konservasi yang luhur.

Keadaan masyarakat yang majemuk, mulai dari hal perekonomian, budaya sampai pada tataran karakater dan kepentingan yang berbeda antar satu individu dengan yang lainnya terkadang menimbulkan gesekan dalam masyarakat. gesekan yang terjadi seringkali mengakibatkan timbulnya sengketa ataupun perselisihan yang bahkan berdampak secara hukum. Perselisihan yang terjadi tidak hanya sebatas individu dengan masyarakat luas, akan tetapi juga terjadinya gesekan antara individu dengan individu dalam lingkup yang lebih kecil.

Restorative Justice atau sering diterjemahkan sebagai keadilan restoratif merupakan suatu model pendekatan yang muncul dalam era tahun 1960-an dalam upaya penyelesaian perkara pidana. Berbeda dengan pendekatan yang dipakai pada sistem peradilan pidana konvensional, pendekatan ini menitikberatkan adanya partisipasi langsung dari pelaku, korban dan masyarakat dalam proses penyelesaian perkara pidana. Restorative justice ini merupakan bentuk lain dari penyelesaiain perselisihan (dispute resolusion) baik formal maupun semi formal yang mencerminkan kecenderungan masa kini dari faham individualisme dan mengurangi fungsi dari negara (Lasmadi, 2010:2). 
Konsep restorative justice pada dasarnya mengandung ukuran keadilan yang tidak lagi mengacu pada teori pembalasan yang setimpal dari korban kepada pelaku (baik secara fisik, psikis atau hukuman), namun perbuatan yang menyakitkan itu disembuhkan dengan memberikan dukungan kepada korban dan mensyaratkan pelaku untuk bertanggungjawab, dengan bantuan keluarga dan masyarakat bila diperlukan (Prayitno, 2012:2).

Selain itu, restorative justice didefinisikan sebagai cara untuk mengembalikan konflik kepada pihak-pihak yang paling terkena pengaruh korban, memberikan keutamaan pada kepentingankepentingan mereka. Restorative justice juga menekankan pada hak asasi manusia dan kebutuhan untuk mengenali dampak dari ketidakadilan sosial dan dalam cara-cara yang sederhana untuk mengembalikan mereka daripada memberikan pelaku keadilan formal atau hukum dan korban tidak mendapatkan keadilan apapun. Kemudian restorative justice juga mengupayakan untuk me-restore keamanan korban, penghormatan pribadi, martabat, dan yang lebih penting adalah sense of control (Susetyo, 2012:10). Penyelesaian perkara pidana di Indonesia mulai mengarah kepada hal tersebut, yaitu melalui mediasi penal.

Berdasarkan hasil wawancara pada 31 Juli 2017 dengan Joko Pramono selaku Bhabinkamtibnas (Bhayangkara Pembina Keamanan dan Ketertiban Masyarakat) di Polsek Tugu, Semarang menyatakan bahwa :

Penyelesaian kasus melalui mediasi penal ditawarkan langsung oleh pihak kepolisian untuk perkara yang tergolong tindak pidana ringan (Tipiring) dan delik aduan. Kendati demikian, ada juga penyelesaian kasus melalui mediasi penal yang berasal dari permintaan pihak yang bersangkutan. Hal tersebut didukung sepenuhnya oleh institusi, karena penyelesaian kasus melalui mediasi penal dianggap lebih humanis

Hal tersebut menggambarkan bahwa penerapan mediasi penal di tingkat kepolisian telah dilaksanakan meskipun masih diterapkan dalam lingkup tindak pidana ringan dan perzinahan. Joko Pramono juga menyatakan bahwa :

Tidak semua perkara dapat diselesaikan dengan mediasi penal. Ada perkara yang memang pihak kepolisian sarankan untuk diselesaikan melalui mediasi penal ada pula perkara tindak pidana yang memang tidak bisa diselesaikan dengan itu. Seperti halnya tindak pidana pencurian dengan kekerasan atau pembunuhan. Pertimbangannya adalah tindak pidana tersebut berkaitan dengan korban nyawa seseorang.

Hal yang sama dijelaskan oleh Kiswoyo, ia mnyatakan bahwa :

Tidak semua perkara pidana dapat diselesaikan melalui mediasi penal. Mediasi penal banyak diterapkan dalam perkara yang merupakan tindak pidana yang dirumuskan secara formil dan terkategori sebagai tindak pidana aduan. Lebih lanjut, mediasi penal baru digunakan ketika perkara pidana tersebut berkaitan erat dengan para pihak serta berdasarkan kesepakatan para pihak pula. Dengan demikian, tidak semua perkara pidana dapat diselesaikan melalui mediasi penal. Namun, ada secercah asa yang layak diperjuangkan, yakni mengoptimalkan mediasi penal untuk perkara-perkara tindak pidana yang berkaitan erat dengan kepentingan korban. 
Meskipun demikian, artinya penerapan hukum di Indonesia mengarah kepada bentuk penyelesaian yang bersifat restorative justice sehingga hal tersebut perlu diapresiasi secara positif oleh masyarakat dan harus ditanggapi dengan terbuka oleh seluruh aparat penegak hukum. Pemikiran terbuka mengenai penerapan mediasi penal juga dikatakan oleh H. SUGENG TIYARTO, S.H.,M.H sebagai Kabag BIN OPS Dirreskrimum Polda Jateng berdasarkan hasil wawancara pada tanggal 23 Oktober 2017. Tugas jabatan tersebut adalah mengawasi serta bertanggungjawab atas segala kegiatan yang terjadi dan merencanakan dan mengendalikan administrasi operasi kepolisian, pengamanan kegiatan masyarakat dan/atau instansi pemerintah, menyajikan informasi dan dokumentasi kegiatan di bagian BIN OPS Dirreskrimum Polda Jateng. Ia menyatakan bahwa :

Penyelesaian melalui mediasi penal boleh saja dilakukan pada tingkat kepolisian namun harus dilihat dari sisi korban, pelaku, serta masyarakat. Kemudian dilihat sejauh mana kepentingannya. Selama hal tersebut tidak mencederai kepentingan serta keadilan masyarakat, dan dirasa adil oleh kedua belah pihak, itu sah sah saja. Kesepakatan harus diambil oleh kedua belah pihak yaitu korban dan pelaku. Namuan tanggapan masyarakat juga perlu diperhatikan untuk tetap memperbaiki citra hukum di Indonesia.

Oleh karena itu, penyelesaian kasus melalui mediasi penal memperhatikan tiga aspek, yaitu korban, pelaku, dan masyarakat. Hal itu sesuai dengan restorative justice dimana nilai-nilainya memperhatikan kembalinya kondisi korban, pelaku, dan masyarakat seperti semula. Mediasi penal layak untuk menjadi alternatif penyelesaian perkara di tingkat kepolisian. Banyak keunggulankeunggulan mediasi penal yang tidak bisa ditemukan dalam penyelesaian kasus melalui peradilan. Berikut beberapa keunggulan mediasi penal (Faisal, 2011 : 85) :

a. Mediasi penal akan mengurangi perasaan balas dendam korban, lebih fleksibel karena tidak harus mengikuti prosedur dan proses sebagaimana dalam sistem peradilan pidana. Karena itu, tentunya lebih sedikit menghabiskan biaya, serta prosesnya lebih cepat dibandingkan dengan proses litigasi (proses penyelesaian perkara di pengadilan)

b.Beban sistem peradilan pidana berkurang karena menumpuknya perkara dan proses penyelesaianya memakan waktu yang tidak sedikit banyak sehingga dapat dikurangi dengan kehadiran mediasi antara pelaku dan korban.

c. Mediasi memberikan kesempatan kepada korban untuk bertemu dengan pelaku untuk membahas kejahatan yang telah merugikan kehidupannya serta mengungkapkan penelitian dan perasaannya serta meminta adanya restitusi.

d.Mediasi menciptakan kembali hubungan yang harmonis antara korban dan pelaku. Kondisi ini tidak ditemukan di dalam penyelesaian konflik melalui sistem peradilan pidana. Pemberian maaf korban kepada pelaku akan mengurangi rasa bersalah pelaku dan menciptakan rekonsiliasi antara keduanya.

Tinjauan Yuridis Penggunaan Mediasi Penal di Tingkat Kepolisian 
Penerapan mediasi penal seringkali terbentur dengan kendala yuridis. Seperti halnya hasil penelitian yang dilakukan oleh Ketut Adi Wirawan (2015) bahwa pelaksanaan mediasi penal dalam penyelesaian tindak pidana ringan di Polresta Denpasar belum berjalan maksimal karena dalam pelaksanaanya harus berhadapan dengan pemikiran positivisme hukum dalam masyarakat dan penyidik. Hal ini menggambarkan tidak seluruh penegak hukum di tataran kepolisian berani untuk menerapkan mediasi penal pada tingkat penyidikan.

Berdasarkan hasil wawancara dengan Bara Sutrisna selaku Kepala Unit Samapta Bhayangkara atau biasa disebut Kanit Sabhara pada tanggal 20 Juli 2017 menyatakan bahwa :

Pada dasarnya, mediasi di Kepolisian tidak dikenal dalam ketentuan undang-undang seperti Undang-Undang Nomor 8 Tahun 1981 tentang Hukum Acara Pidana atau di dalam Undang-Undang Nomor 2 Tahun 2002 tentang Kepolisian Negara Republik Indonesia juga tidak diatur mengenai mediasi oleh pihak kepolisian. Akan tetapi, mediasi penal dapat dilihat dalam Surat Kapolri No Pol: B/3022/XII/2009/SDEOPS tanggal 14 Desember 2009 tentang Penanganan Kasus Melalui Alternatif Dispute Resolution

Surat Kapolri berada di bawah tataran undang-undang sehingga dianggap belum terlalu kuat untuk dijadikan sebagai landasan yuridis dalam menerapkan mediasi penal terhadap penyelesaian kasus yang ada di kepolisian. Hal tesebut yang menjadi dilematis dalam penerapan mediasi penal. Latar belakang keluarnya Surat Kapolri tersebut karena banyaknya kriminalisasi terhadap tindak pidana ringan pada tahun yang sama. Misalnya seperti kasus pencurian 3 buah kakao oleh nenek Minah berusia 55 tahun yang berujung pada pidana 1 bulan 15 hari penjara dengan masa percobaan 3 bulan. Hal itu tentu tidak sepadan dengan kerugian yang diderita oh PT RSA pemilik pohon kakao yang melaporkan perkara tersebut. Kasus tersebut hanya sebagian kecil yang terjadi pada tahun 2009 sehingga Kapolri mengeluarkan Surat Kapolri No Pol: B/3022/XII/2009/SDEOPS tanggal 14 Desember 2009 tentang Penanganan Kasus Melalui Alternatif Dispute Resolution yang berisi sebagai berikut :

1) Mengupayakan penanganan kasus pidana yang mempunyai kerugian materi kecil, penyelesaiannya dapat diarahkan melalui konsep ADR

2) Penyelesaian kasus pidana dengan menggunakan ADR harus disepakati oleh pihak-pihak yang berperkara namun apabila tidak terdapat kesepakatan baru diselesaikan sesuai dengan prosedur hukum yang berlaku secara profesional dan proporsional.

3) Penyelesaian kasus pidana yang menggunakan ADR harus berprinsip pada musyawarah mufakat dan harus diketahui oleh masyarakat sekitar dengan menyertakan RT RW setempat

4) Penyelesaian kasus pidana dengan menggunakan ADR harus menghormati norma hukum sosial / adat serta memenuhi azas keadilan

5) Memberdayakan anggota Polmas dan memerankan FKPM yang ada di wilayah masing2 utk mampu mengidentifikasi kasus-kasus pidana yang mempunyai kerugian materiil kecil dan memungkinkan untuk diselesaikan melalui konsep ADR. 
6) Untuk kasus yang telah dapat diselesaikan melalui konsep ADR agar tidak lagi di sentuh oleh tindakan hukum lain yang kontra produktif dengan tujuan Polmas.

Selain Surat Kapolri tersebut, belum ada landasan yuridis yang lebih kuat yang dapat menjadi dasar bagi penerapan mediasi penal di tingkat kepolisian. Pada beberapa wilayah, aturan mengenai mediasi penal bisa diatur lebih khusus seperti Peraturan Kapolres sama halnya yang diatur dalam Peraturan Kapolres Tentang Mediasi Penyelesaian Perkara atau Restorative Justice Perkara Pidana pada Tingkat Penyidikan di Lingkungan Polres Dharmasraya, namun belum semua wilayah mengeluarkan aturan tersebut. Sampai saat ini, hanya Surat Kapolri tersebut yang menjadi landasan para aparat kepolisian menerapkan mediasi penal dalam menyelesaikan kasus. Berdasarkan hasil wawancara dengan Kiswiyono, S.H selaku penyidik di Unit 3 Subdit 1 Kamneg Dirreskrimum Polda Jateng menyatakan lebih lanjut bahwa meskipun mediasi penal belum ada landasan hukum yang kuat, tapi penyelesaian kasus melalui mediasi penal sangat dimungkinkan untuk dilaksanakan dengan berpegang pada prisip kepastian hukum, kemanfaatan hukum, dan keadilan hukum.

Lembaga Kepolisian mempunyai kewenangan untuk menentukan apakah suatu perbuatan diteruskan atau tidak diteruskan dalam proses peradilan pidana dengan alasan-alasan tertentu (Kandati, 2013: 109). Misalnya dalam kecelakaan lalu lintas, apabila hanya menimbulkan kerugian yang kecil atau luka yang kecil biasanya diselesaikan dengan mediasi di antara pelaku dan korban, serta pihak kepolisian sebagai saksi atas kesepakatan yang dicapai, perkara tidak diteruskan atas dasar kesepakatan bersama antara pelaku dan korban. Namun demikian jika kecelakaan akibat kelalaian tersebut menimbulkan kerugian yang besar seperti nyawa, maka mediasi tidak dapat dilakukan, adapun pembayaran ganti kerugian berupa biaya rumah sakit dan penguburan jenazah korban hanya sebagai salah satu pertimbangan yang nantinya digunakan oleh hakim dalam menjatuhkan putusan kepada terdakwa. (Romli, $2008: 2$ )

1.4 Bentuk Mediasi Penal yang Digunakan dalam Penyelesaian Perkara Pidana di Tingkat Kepolisian

Mediasi penal dikenal dalam beberapa bentuk, yaitu informal mediation traditional village or tribals moots, victim-offender mediation, reparation negotiation programmes, community panels or courts, dan family and community group conferences. Pengertian dari masing-masing bentuk tersebut telah dijelaskan dalam bab sebelumnya. Penerapan bentuk mediasi penal dapat dilihat dari proses penyelesaiannya. Faktor yang dapat mempengaruhi penggunaan bentuk medasi penal diantaranya adalah jenis tindak pidana, adat istiadat, dan keinginan kedua belah pihak baik tersangka maupun korban.

Penentuan bentuk mediasi penal apa yang digunakan tentunya harus memperoleh contoh konkret mengenai suatu kasus yang telah diselesaikan melalui mediasi penal. Berdasarkan hasil wawancara sebagai bahan analisis, Polsek Tugu Semarang pernah menyelesaikan suatu kasus tindak pidana penganiayaan ringan pada bulan Juni 2016 yang terjadi di wilayah pakintelan. Penganiayaan 
tersebut bermula dari kesalahpahaman kecil pacar dari tersangka yang mengaku digoda oleh korban yang notabenenya masih satu desa hanya saja beda RT. Tersangka tidak terima dengan hal tersebut dan ingin memberi pelajaran terhadap korban dengan menganiayanya bersama 4 orang lain. Setelah itu orang tua korban tidak terima dan melaporkan hal tersebut kepada ketua RT dan RW, setelah itu ketua RT dan RW menghubungi pihak bhabinkamtibmas guna melakukan proses mediasi. Dalam hal ini polisi menjadi mediator yang dilaksanakan di kelurahan. Mediasi tersebut diikuti oleh korban, dan pelaku. Dari uraian tersebut, dapat diketahui bahwa bentuk mediasi penal yang digunakan pada penyelesaian kasus di tingkat kepolisian ini adalah victim-offendrr mediation. Hal tersebut juga dikuatkan oleh Kiswoyo yang menyatakan bahwa hal terpenting dari penyelesaian perkara adalah mempertemukan kedua belah pihak dan menemukan kesepakatan yang masing-masing menyetujui kesepakatan tersebut tanpa paksaan.

Model victim offender mediation atau biasa disingkat dengan VOM juga banyak digunakan diberbagai negara untuk menyelesaikan perkara pidana diluar pengadilan (Faisal, 2011 : 81). Dewasa ini penggunaan mediasi dalam sistem peradilan pidana tumbuh dan berkembang sangat pesat. Tidak sedikit para ahli hukum pidana yang menyerukan perlunya diadakan program-program yang bertujuan mempertemukan korban dan pelaku sehingga masalah yang mereka hadapi dapat diselesaikan dengan baik dan situasi kembali berjalan dengan normal (Bakker, 2007:1480). Hal tersebut juga telah terjadi di Indonesia sekarang ini.

Victim offender mediation dianggap model mediasi yang paling sederhana dan dapat memenuhi rasa keadilan bagi kedua belah pihak. Karena mediasi dalam hukum pidana berarti proses penyelesaian perkara pidana dengan mempertemukan pelaku kejahatan dan korban untuk mencapai kesepakatan bersama berkaitan dengan kejahatan yang dilakukan pelaku dan restitusi yang diberikan kepada korban. Dengan bertemunya kedua belah pihak yang bersangkutan dalam suatu forum mediasi, kedua belah pihak dapat menyampaikan aspirasi mereka sendiri secara langsung. Seorang pelaku dapat menyampaikan latarbelakang ia melakukan suatu tindak pidana yang merugikan korban serta seorang korban dapat menyampaikan perasaan dan tuntutan-tuntutan yang ingin ia kemukakan. Pertemuan tersebut tentunya ditengahi oleh seorang mediator. Dalam hal ini, perangkat desa atapun aparat kepolisian kerap menjadi mediator dalam penyelesaian perkara. Pada kasus yang telah disebut diatas, sebenarnya bisa saja kasus tersebut diselesaikan oleh perangkat desa saja, tetapi untuk memberikan kesan kepastin hukum, perangkat desa mengundang Bhabinkatibmas untuk ikut serta dalam mediasi.

Dengan dipertemukannya kedua belah pihak, harapannya dapat secara bertahap merubah paradigma hukum pidana yang terkesan statis, kaku, dan positivistik dalam menyelesaikan perkara ke arah yang lebih progresif dan humanis. Perubahan tersebut juga harapannya dapat memenuhi rasa keadilan bagi masyarakat. 
VOM muncul karena beberapa latar belakang. Salah satunya adalah pengaruh tribal moots yang dahulu eksis di Indonesia sebagai penyelesaian perselisihan yang hadir di tengah-tengah masyarakat. Selain itu, VOM muncul karena sistem peradilan yang berlaku di Indonesia terlalu bersifat positif legalistic sehingga tidak bisa menjamin rasa keadilan terutama bagi korban.

Keadilan restoratif juga memberikan dampak bagi kemunculan VOM dimana keadilan restoratif membutuhkan suara bagi korban tindak pidana sehingga dapat dilihat bagaimana keadilan akan tercapai menurut sudut pandang korban. Bagi keadilan restoratif, penyelesaian melalui mediasi penal dengn model VOM sangat membantu hal tersebut. Restoratif membutuhkan peran serta pelaku, korban, serta masyarakat agar seluruh akibat ataupun latarblakang terjadinya suatu tindak pidana dapat terselesaikan melalui VOM.

Fokus utama Victim-Offender Mediation adalah menempatkan pelaku dan korban kejahatan sebagai bagian dari sistem peradilan pidana. Korban diberi hak untuk bertanya kepada pelaku mengapa dia menjadi korban, tujuannya adalah agar pelaku bertanggungiawab atas tindakannya (Wellikoff, 2004 : 2). Selain itu, korban juga dapat memberikan tuntutan lain agar pelaku dapat mempertanggungjawabkan perbuatannya, bukan hanya pemidanaan. Tanpa pidana, kasus dapat terselesaikan dengan jalan yang dianggap adil bagi kedua belah pihak.

Untuk menyelesaikan kasus melalui model Victim-Offender Mediation setidaknya ada 4 tahapan yang perlu dilaksanakan (Faisal, 2011: 87). Hal ini juga di tegaskan oleh Joko Pramono saat menyelesaikan kasus melalui mediasi penal khususnya dengan Victim-Offender Mediation. Pertama, tahap In take atau masukan. Pada tahap ini, penyidik mendalami kasus apakah perkara tersebut bisa diselesaikan melalui mediasi penal atau tidak. Hal tersebut dapat dilihat dari jenis tindak pidana, motif pelaku, dan keadaan korban. Kesepakatan pihak korban juga sangat menentukan fase ini karna tanpa adanya peran korban, VOM tidak akan dilaksanakan. Berdasarkan hasil wawancara, Sugeng Tiyarto memiliki pandangan mengenai hal itu :

"Menurut saya, penyelesaian melalui mediasi penal bisa dilakukan pada berbagai tindak pidana, seperti pencurian, penggelapan, dan seluruh tindak pidana yang bersifat delik formil asalkan ada kesepakatan dari pihak korban. Setelah kedua belah pihak mencapai kesepakatan, penyidik tidak lagi berhak melakukan suatu tindakan atas perkara tersebut.

Pada fase ini, kerelaan korban untuk menyelesaikan perkara diluar pengadilan menjadi titik penting keberlanjutan mediasi. Fase kedua adalah persiapan konfrontasi. Pada fase ini mediator mendalami aspirasi yang akan disuarakan para pihak agar mencapai kesepakatan dan memberikan arahan-arahan. Fase ketiga adalah mediasi itu sendiri. Proses mediasi lebih difokuskan pada dialog daripada pemenuhan kesepakatan pemberian restitusi memunculkan rasa empati dan pemahaman antara korban dan pelaku. Fase ini dimulai dengan aturan-aturan yang harus diikuti kedua belah pihak, kemudian dilanjutkan dengan pemberian kesempatan kepada korban untuk menceritakan kejahatan 
yang menimpanya.Setelah itu, pelaku juga diberi kesempatan untuk merespon keluhan-keluhan korban, menjelaskan mengapa kejahatan itu terjadi dan meminta maaf. Pembicaraan mengenai kerugian korban, kesepakatan repamsi yang memuaskan kedua belah pihak merupakan langkah berikutnya yang harus dijalankan oleh mediator. (Shenk, 2001: 194-195).

Fase terakhir adalah pelaksanaan hasil kesepakatan mediasi. Pada tahap kepolisian, mediasi penal memang belum memiliki kekuatan hukum yang mengikat sehingga hasil kesepakatan dituangkan dalam bentuk surat yang ditandatangani diatas materai sehingga memiliki kekuatan hukum. Pada kesepakatan tersebut, saksi-saksi dari kedua belah pihak juga dicatutkan.

\section{D.2 Peran Aparat Penegak Hukum dalam Mediasi Penal}

Seperti yang kita ketahui bahwa ada beberapa cara yang bisa ditempuh agar suatu perkara sampai ke kepolisian, yaitu berdasarkan laporan atau pengaduan, diketahui sendiri oleh penyidik, atau tertangkap tangan. Dari situlah hukum acara pidana mulai bekerja. Penyelesaian melalui mediasi penal di tingkat kepolsian tentu dimulai pula dari hal-hal tersebut. Setelah itu, Joko Pramono menjelaskan bahwa :

Pihak kepolisian selalu menawarkan secara langsung terhadap kasus perkara tindak pidana ringan untuk menyelesaikannya melalui jalur mediasi penal. Namun adakalanya pihak yang bersangkutan yang meminta sendiri untuk diselesaikan melalui mediasi penal. Aparat desa terkadang meminta secara langsung polisi sebagai mediator pada proses penyelesaiannya. Itu dikarenakan agar mediasi penal memiliki kekuatan hukum dan dipercaya oleh masyarakat.

Hal itu menunjukkan bahwa aparat hukum di tingkat kepolisian sudah mulai membuka mediasi penal sebagai salah satu metode penyelesaian kasus hukum. Pada dasarnya, dalam memediator aparat kepolisian menerima segala aspirasi dari seluruh pihak mengenai bagaimana proses mediasi itu berjalan. Sugeng Tiyarto selaku penyidik yang bertugas di Polda Jateng mengemukakan bahwa :

Pihak kepolisian tidak pernah menghalangi penyelesaian perkara diluar pengadilan. Saat ini malah penyelesaian perkara melalui mediasi penal lebih baik dilakukan jika kedua belah pihak sepakat akan hal itu. Biasanya, inisiatif itu datang dari pelapor dan terlapor. Pihak kepolisian hanya memberikan saran kepada kedua belah pihak. Polisi berperan sebagai fasilitator, siap menampung aspirasi dari kedua belah pihak. Selama ada kesepakatan, pihak kepolisian tinggal mewadahi hal tersebut.

Dari uraian tersebut, ada beberapa peran aparat penegak hukum dalam hal ini polisi dalam menyelesaikan kasus melalui mediasi penal. Pertama, polisi sebagai fasilitator bagi kedua belah pihak. Kedua, polisi juga kerap berperan sebagai mediator dalam mediasi penal.

\section{E. SIMPULAN DAN SARAN}

Berdasar atas analisis dan pembahasan yang telah dikemukakan dalam bab sebelumnya, dapat ditarik kesimpulan bahwa bentuk mediasi penal yang digunakan pada tingkat kepolisian adalah Victim 
Offender Mediation. Pada kasus dengan tindak pidana ringan, polisi menawarkan secara aktif untuk menyelesaikannya di luar pengadilan melalui mediasi kemudian untuk perkara dengan tindak pidana biasa, inisiatif penyelesaian melalui mediasi penal muncul dari pelapor ataupun terlapor. Landasan yuridis penerapan mediasi penal di tingkat kepolisian adalah Surat Kapolri No Pol: B/3022/XII/2009/SDEOPS tanggal 14 Desember 2009 tentang Penanganan Kasus melalui Alternatif Dispute Resolution. Berbeda dengan penerapan mediasi penal pada tahap penuntutan yang belum mempunyai payung hukum sehingga perkara pidana yang masuk sebagai delik biasa tetap dilanjutkan penuntutannya meskipun terjadi kesepakatan antara pelaku dan korban. Akan tetapi, dalam hal perkara pidana yang berupa delik aduan, apabila terjadi kesepakatan antara pelaku dan korban yang membuat korban mencabut aduan terhadap pelaku bisa menjadi alasan penghentian penuntutan sebagaimana diatur dalam Pasal 75 KUHP. Selain itu, bentuk mediasi penal yang telah ada payung hukum dan dijalankan oleh Jaksa Penuntut Umum adalah diversi atau penyelesaian perkara pidana anak yang diatur dalam Undang-Undang Nomor 11 Tahun 2012 Tentang SPPA dengan tujuan mendapatkan keadilan restoratif. Peran aparat penegak hukum dalam hal ini polisi dalam menyelesaikan kasus melalui mediasi penal. Pertama, polisi sebagai fasilitator bagi kedua belah pihak. Kedua, polisi juga kerap berperan sebagai mediator dalam mediasi penal.

Saran yang dapat disampaikan melalui kesimpulan diatas adalah sebagai berikut : lembaga kepolisian ataupun kejaksaan perlu dirumuskan dalam bentuk aturan hukum yang dapat dijadikan payung hukum agar access to justice baik di dalam maupun di luar pengadilan dapat terpenuhi. Penuntut Umum harus lebih terbuka dalam menanggapi kasus-kasus yang bisa diselesaikan melalui mediasi penal. Keadilan yang restoratif sejatinya ada pada pelaku, korban, dan masyarakat. Apabila ketiga aspek tersebut tidaklah menganggap itu hal yang perlu dipidana, meskipun telah pada tingkat penuntutan, penyelesaian melalui mediasi penal lebih diperlukan.

\section{F. DAFTAR PUSTAKA}

Arief, Barda Nawawi. 2010. Mediasi Penal : Penyelesaian Perkara di Luar Pengadilan. Semarang : Pustaka Magister 2012. Mediasi Penal : Penyelesaian Perkara di Luar Pengadilan. Semarang : Pustaka Magister 
Bako, Ronny Sautma Hotma. 1995. Hubungan Bank dan Nasabah Terhadap Produk Tabungan dan Deposito (Suatu Tinjauan Hukum Terhadap Perlindungan Deposan di Indonesia Dewasa ini). Bandung : Citra Aditya Bakti

D.Fisher, Bruce, dan Marianne Moody Jennnings. 1986. Law For Business. St.Paul: West Publishing Company

Ehrlich, Eugen. 1936. Fundamental Principles of the Sociology of Law, diterjemahkan oleh Walter Moll. 1962 New York: Russell and Russell

Freeman, M.D.A. 2001. Lylod's Introduction to Jurisprudence. London: Sweet\&Maxwell LTD

Godpaster, Garry. 1995. Tinjauan Terhadap Penyelesaian Sengketa : Seri Dasar-dasar Hukum Ekonomi Arbitrase Di Indonesia. Jakarta: Ghalia Indonesia

Margono, Suyud. 2000. ADR dan Arbitrase Proses Pelembagaan dan Aspek Hukum. Jakarta : Ghalia Indonesia

Marzuki, Peter Mahmud. 2005. Penelitian Hukum. Jakarta : Raja Grafindo Persada

Miles dan Huberman. 1984. Analisis Data Penelitian Kualitatif. Diterjemahkan oleh Tjetjep Rohendi Rohidi. Jakarta:UI Press.

Moleong, Lexy J. 2002. Metode Penelitian Kualitatif. Bandung: Remaja Rosdakarya

N.Corley, Robert dan O.Lee Reed. 1987. The Legal Environment of Business. New York: MgGrawHill Book Company

Prajogo, Soesilo. 2007. Kamus Lengkap Hukum (Internasional dan Indonesia). Wipress

Putro, Widodo Dwi. 2011. Kritik Terhadap Paradigma Positivisme Hukum. cetakan Pertama. Yogyakarta: Genta Publishing

Rahardjo, Satjipto. 2007. Biarkan Hukum Mengalir (Catatan Kritis tentang Pergulatan Manusia dan Hukum), Jakarta: Kompas Media Nusantara

2009. Hukum Progresif (Sebuah Sintesa Hukum Indonesia), Yogyakarta: Genta Publishing

Soemartono, Gatot. 2006. Arbitrase dan Mediasi di Indonesia. Jakarta: Gramedia Pustaka Utama

Syamsudin,M..2008. Artikel yang berjudul "The Burden of Indigenous People In Dealing with State Regulation" (Jurnal Hukum Vol.15 No.3, 2008)

Syafa'at, Rachmad. 2008. Metode Advokasi dan Alternatif Penyelesaian Sengketa. Malang: Instrans Publishing

Usman, Rachmadi. 2003. Pilihan Penyelesaian Sengketa di Luar Pengadilan. Bandung : Citra Aditya Bhakti

W.Moore, Christopher. 1996. The Mediation Process: Practical Strategies for Resolving Conflict. San Fransisco: Jossey-Bass Publishers 
Reksodiputro, Mardjono. 1993. Sistem Peradilan Pidana Indonesia (Melihat Kepada Kejahatan Dan Penegakan Hukum Dalam Batas - Batas Toleransi). Fakultas Hukum Universitas Indonesia

Muladi. 1995. Kapita Selekta Sistem Peradilan Pidana. Semarang: Universitas Diponegoro

Romli Atmasasmita. 1996. Sistem Peradilan Pidana (Criminal Justice System) Perspektif Eksistensialisme Dan Abolisionalisme. Jakarta: Bina Cipta

\section{ARTIKEL}

Ali, Mahrus. 2010. Artikel yang berjudul "Akomodasi Nilai-nilai Budaya Masyarakat Madura Mengenai Penyelesaian Carok Dalam Hukum Pidana" Jurnal Hukum No.1 Vol.17, Januari 2010 .

Atmasasmita, Romli, 2008, "Sinergi Kerja Polri Dan Kejaksaan Agung Dalam Sistem Peradilan Pidana di Indonesia," Makalah disampaikan pada Seminar Hubungan Polisi - Jaksa: Menuju Integrasi, di Auditorium Bumi Putera -Fakultas Ilmu Sosial dan Ilmu Politik Univ. Indonesia, Depok, 17 April 2008

Bakker, Mark William. 1994. "Repairing The Breach and Reconciling the Discordant: Mediation in the Criminal Justice System", North Carolina Law Review, No.72,

Cappelletti, Mauro dan Bryant Garth (Eds), Acces To Justice : Book I, Supra note 1.

Djohansjah, J. Makalah yang berjudul “Akses Menuju Keadilan”. Disampaikan Pada Pelatihan HAM Bagi Jejaring Komisi Yudisial Bandung, 3 Juli 2010

Ependi. 2015. Artikel yang berjudul "Proses Penyelesaian Tindak Pidana Yang Dilakukan oleh Anak Berdasarkan Undang Undang Nomor 11 Tahun 2012 Tentang Sistem Peradilan Pidana Anak" Jurnal Keadilan Volume 15 No 1, Juni 2015.

Faisal. 2011. Mediasi Penal sebagai Alternatif Penyelesaian Perkara Diluar Pengadilan. Jurnal Pranata Hukum, Volume 6 Nomor 1, Januari 2011.

Kandati, Herry. 2013. "Penerapan Mediasi oleh Lembaga Kepolisian Republik Indonesia dalam Penangganan Tindak Pidana Sebagai Perwujudan Restorasi Justitia." Repository Universitas Sam Ratulangi Volume 1 Nomor 5, Oktober-Desember.

Surbakti, Natangsa. 2011. "Mediasi Penal Sebagai Terobosan Alternatif Perlindungan Hak Korban Tindak Pidana.” Jurnal Ilmu Hukum. Volume 14 Nomor 1, Maret 2011.

Syamsudin,M..2008. Artikel yang berjudul "The Burden of Indigenous People In Dealing with State Regulation" Jurnal Hukum Vol.15 No.3, 2008.

Taufiq, Muhammad. 2013. Artikel yang berjudul "Penyelesaian Perkara Pidana Berkeadilan Substansial". Jurnal Yustisia, Edisi 25 Januari-April.

Wirawan, Ketut Adi. 2015. Urgensi Pelaksanaan Mediasi Penal Di Tingkat Penyidikan Dalam Penyelesaian Tindak Pidana Penganiayaan Ringan Di Kepolisian Resort Kota Denpasar. Thesis pada Universitas Udayana.

Wulandari, Cahya. Call for Paper in International Symposium Pierre Bourdieu: A Reflexive Sociology of Law and Society. "Penal Mediation as an alternative dispute settlement of criminal based on the culture society". Yogyakarta: Thafa Media. p.327-338 
. Call for Paper dalam Kongres Ilmu Hukum Refleksi dan Rekonstruksi Ilmu Hukum Indonesia: "Penyelesaian Malpraktik Medik: Omkering Van Het Bewijslat atau Penal Mediation". Yogyakarta: Thafa Media. Hlm.353-372 